\title{
SÍDLA LEŽIACE V ZÁZEMÍ MIEST V ČASE A PRIESTORE
}

\author{
SETTLEMENTS LOCATED IN THE BACKROUND CITIES IN TIME AND SPACE
}

\author{
doc. Ing. arch. Alžbeta Sopirová, Ph.D.
}

\begin{abstract}
ABSTRAKT
Slovensko sa vyznačuje rôznou intenzitou decentralizačných tendencií. Podstata tohto procesu spočíva v priestorovom premiestňovaní obyvatel'stva - ich návrat alebo únik z jadra mesta na jeho okraj, zvyšovaní miery urbanizácie prímestskej zóny, čo má dopad na štruktúru vidieckeho osídlenia a urbanizáciu krajiny. Príspevok sa t’ažiskovo venuje dopadu suburbanizačného procesu na priestorové prejavy rozvoja urbánnej štruktúry vidieckych sídiel Bratislavskej aglomerácie, ktorá patrí k priestorom najintenzívnejšie atakovaným novými investičnými zámermi.
\end{abstract}

Klíčová slova: zázemie mesta, suburbánna zóna, vidiecke sídla, rozvoj urbánnenej štruktúry

\section{ABSTRACT}

Slovakia is characterized by different intensities of decentralization tendencies. The nature of this process lies in the spatial movements of the population - their return or an escape from the city core to the edge, increasing rates of urbanization suburban area, which has an impact on the structure of the rural population and urbanization of the country. The paper deals with focal impact of suburbanization processes on spatial manifestation of urban infrastructure development of rural settlements of the Bratislava agglomeration, one of the most intense areas attacked by new investment plans.

Key words: background city, suburban area, rural settlements, development of urban structure

\section{SÚČASNÝ STAV PROBLEMATIKY NA SLOVENSKU}

Zmena režimu na Slovensku po roku 1990, následné zavedenie trhového prostredia a jeho sprístupnenie hypotekárnymi úvermi, vyvolalo proces decentralizácie niektorých, pôvodne mestských funkcií do sídiel ležiacich v zázemí miest. V týchto sídlach sa postupne prejavuje transformácia sociálneho a fyzického prostredia z vidieckeho na (pred)mestské - suburbánne. Sprievodným znakom tohto procesu je odliv obyvatel'ov z mesta, ich st’ahovanie do sídiel v jeho zázemí. Súvisí to s túžbou obyvatel'ov po pokojnejšom, kvalitnejšom bývaní, v atraktívnejšom prostredí, v dostupnosti práce a služieb, ktoré sú sústredené v jadrovom meste.

Na Slovenku, v dynamicky sa rozvíjajúcich regiónoch, suburbanizačný proces spôsobil extenzívne prerastanie, tzv. „rozsídl’ovanie“ ' t’ǎiska osídlenia do okrajových častí mesta a prímestskej zóny. Táto zóna je tvorenej okolitými vidieckymi sídlami a „medzipriestorom“, t.j. priestorom vol’nej krajiny, ktorá vypĺn̆a územie medzi zastavanými plochami a funkčne heterogénnymi areálmi.

Medzipriestor, ak nie je dostatočne legislatívne chránený, môže byt’ potenciálnym územím pre prienik nových funkcií, ktoré sú z rôznych dôvodov vyčleňované z intravilánu mesta (dopravná a technická infraštruktúra, podnikatel'ské a obchodné zóny, výrobné a skladové areály, rekreačné a zábavné centrá a hlavne rezidenčné zóny). „Intenzita dosahu účinnosti priestorového rozpínania t’ažiska osídlenia do zázemia je úmerná pozícii mesta v sídelnej štruktúre, jeho vel'kosti a atraktivite ako aj hospodárskej dynamike rozvoja regiónu. Prienikom nových funkcií do katastrálnych území vidieckych sídiel môžu tieto získavat nové rozvojové stimuly a zdroje príjmov" (Sopirová, 2013, s. 7). 


\section{RESIDENČNÁ SUBURBANIZÁCIA V PODMIENKACH SLOVENSKA}

Rezidenčné podnikatel'ské stratégie na Slovensku realizujú svoje zámery v sídlach ležiacich v záujmovom území miest, s ciel’om obsadzovat' „vol’ný priestor“, vyhl’adávat'a skupovat' disponibilné a ekonomicky výhodné pozemky. Tento proces je sprevádzaný plošnou expanziou, kvantitatívnym rastom týchto sídiel na úkor plôch pol’nohospodárskej často aj lesnej pôdy. Vplyvom suburbanizácie sa hranice medzi mestom a jeho zázemím stavajú čoraz menej zretel’nými. Jednotlivé priestory sa navzájom ovplyvňujú, dopĺn̆ajú a potrebujú, dá sa konštatovat', že „vzt'ah medzi dnešným aglomerovaným zázemím a mestom je vztahom závislosti“ (Hnilička, 2005, s. 27). Vzniká akési „prechodné územie“, v ktorom sa miešajú mestské aj vidiecke znaky, miera urbanity a rurality, je to priestor prelínania rôznorodých sociálnych a kultúrnych charakteristík.

Nová rezidenčná výstavba je sprevádzaná množstvom dlhodobo neriešených problémov. Prebiehajúci stavebný rozvoj sa dá charakterizovat' ,investičnými zámermi často bez jasnej koncepcie, ktoré na seba nenadväzujú, pôsobia viac chaoticky či individualisticky“"(Smolec, 2016, s. 2).

Medzi najzávažnejšie problémy rezidenčnej výstavby radíme:

- sociálne, ktoré sa prejavujú polarizáciu a často napätím medzi pôvodnou komunitou a novými obyvatel'mi - „výsledky štatistického prieskumu so 135 respodentami preukázali, že viac ako 50\% obyvatel’ov sa nových developerských projektov skôr obáva“" (Štefancová, 2014, s. 75);

- priestorové, ktoré sa vyznačujú živelnou, rozbujnenou výstavbou, ktorá mení hmotovopriestorovú štruktúru a architektonický dizajn pôvodného územia, narúša koexistenciu obce s okolitou krajinou, vytvára nové dominanty, priehl'ady a prináša nezvratné zmeny do obrazu a siluety sídla (obr. č. 1);

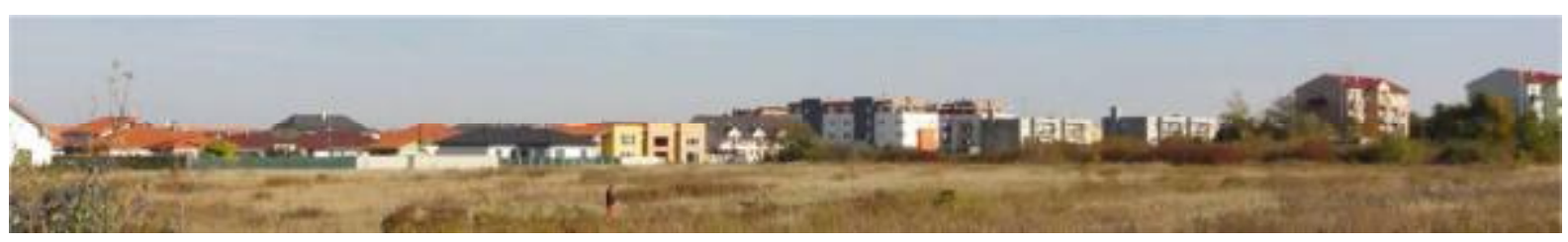

Obr. 1 Živelná výstavba nových obytných zón mení hmotovo-priestorový obraz sídla - obec Rovinka, ktorá leží v zázemí Bratislavy /foto: Sopirová, 2013/

- funkčné, ktoré sa odrážajú v kvantitatívne a často aj kvalitatívne nepostačujúcej základnej obchodnej a školskej vybavenosti, chýbajúcich službách, zariadeniach pre šport a relax, čo spôsobuje každodennú migráciu „,novousadlíkov“;

- ekonomické, ktoré v dôsledku nových, často vynútených investícií, zvyšujú rozpočet obce;

- ekologické, sprevádzané zmenou priorít vo využívaní krajiny, porušením dlhodobo vytváranej krajinnej štruktúry, fragmentáciou a degradáciou ekosystémov, znižovaním ekologickej stability;

- infraštrukturálne, ktoré vyvolávajú zát'až na existujúcu technickú infraštruktúru, ktorá nie je dimenzovaná na požadované zvýšené kapacity,

- dopravné - nové územia nie sú pokryté hromadnou dopravou, obyvatelia sú závislí na automobilovej doprave, čo spôsobilo neplánovanú zát'až na regionálnu komunikačnú siet'. 


\section{ZNAKY NOVEJ OBYTNEJ VÝSTAVBY V ZÁZEMÍ BRATISLAVY}

Bratislavská aglomerácia patrí k najdynamickejšie sa rozvíjajúcim mestským regiónom Slovenska. Rezidenčná suburbanizácia sa v tomto priestore realizuje v niekol'kých vývojových etapách - nástup sa začal prejavovat' v od polovice 90-tych rokov minulého storočia, na intenzite nabrala v období rokov 2002 až 2009. Prispela k tomu platná legislatíva, ktorá umožnila zjednodušený proces povol'ovania investičných zámerov vo vidieckych sídlach s počtom do 2000 obyvatel’ov, len na základe územnoplánovacieho podkladu. Mierna stagnácia suburbanizačného procesu nastala v rokoch 2010 2015, ako odraz presýtenia realitného trhu, pri ktorom ponuka volných plôch výrazne prevýšila potenciálny dopyt. V súčasnosti trh s nehnutel’nost'ami opät' ožíva, záujem je však hlavne o byty v meste. Rozvoj satelitných lokalít stagnuje. Investori si postupne uvedomujú, že okrem pekného rodinného domu musia potencionálnemu záujemcovi ponúknut’ aj ,pridanú hodnotu“.

Pri upriamení pozornosti na stavebný "boom“, ktorý sa za ostatné roky realizoval v suburbanizačnom zázemí Bratislavy, môžeme konštatovat', že najviditel'nejšími stavebnými zásahmi sú poznačené vidiecke sídla, ktoré sa nachádzajú vo vzdialenosti cca 20 až $30 \mathrm{~km}$ od centra a súčasne ležia pozdliž hlavných dopravných a sídelných rozvojových osí, ktoré expandujú aj na územia susedných štátov Rakúska a Mad’arska. Medzi rozhodujúce kritéria pre priestorovú lokalizáciu rezidenčnej funkcie patrí kvalita životného prostredia a atraktivita krajiny, v ktorej sa sídlo nachádza. Rozsiahla výstavba je spravidla výsledkom vstupu silného investora do územia, ktorý realizuje rodinné aj bytové domy v existujúcej štruktúre aj v okrajových častiach. Vidiecke sídla sú postupne „prerastané“ novými objektmi a „obrastané“ obytnými zónami.

Novú rezidenćnú obytnú výstavbu charakterizujú nasledovné znaky:

- priestorová segregácia, ktorá sa prejavuje porušením historicky vytváranej pôdorysnej stopy a urbánnej textúry, vznikom novej matrice ulíc, ignorujúcej existujúce vzt’ahy a väzby na pôvodnú hmotovo-priestorovú a funkčno-prevádzkovú štruktúru (obr. č. 2), často vytvára nepriechodné bariéry $\mathrm{v}$ území v podobe slepých ulíc, uzavretých pre verejnost', ktoré nahrádzajú absentujúce verejné priestory v obytných zónach (obr. č. 3);
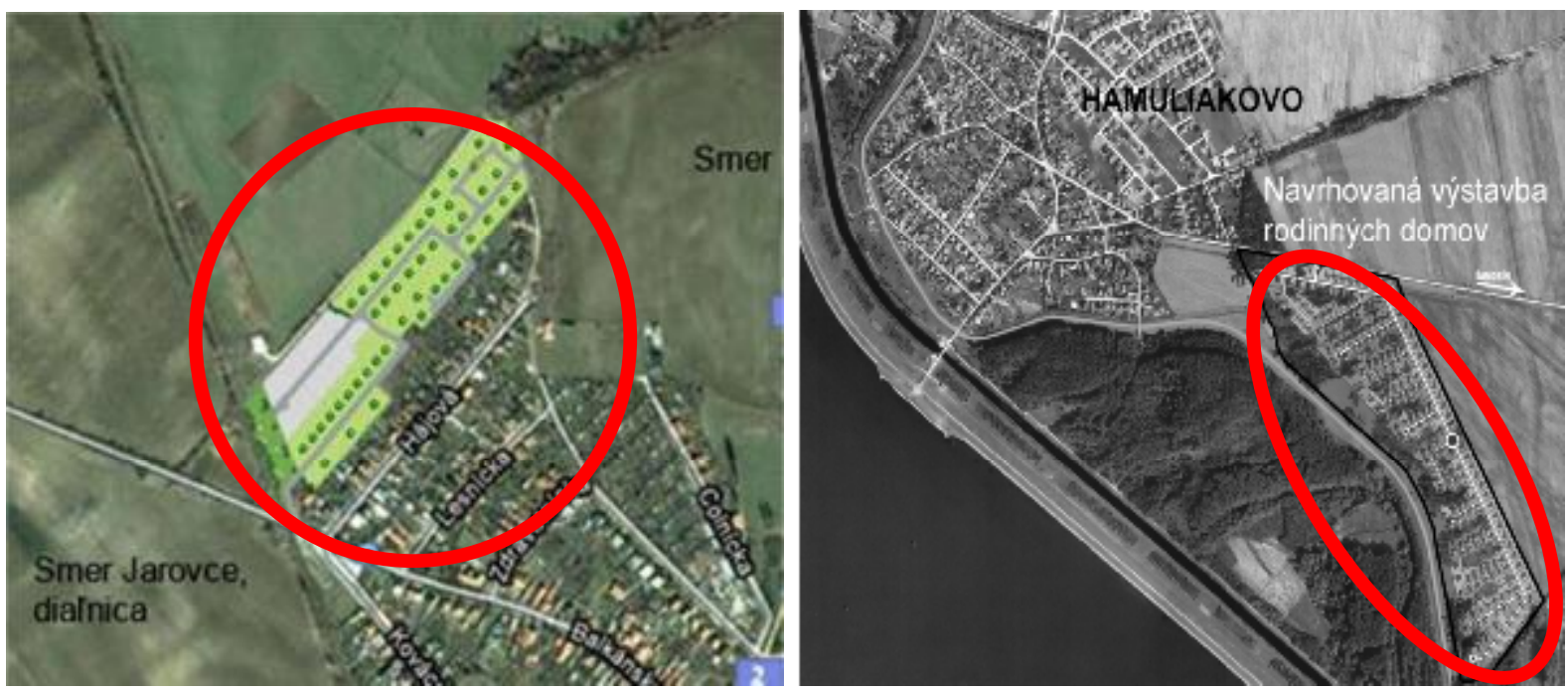

Obr. 2 Chýba vzájomná väzba medzi novou a pôvodnou štruktúrou - Bratislava MČ Rusovce Obr. 3 Hrebeňová uličná štruktúra so slepými ulicami - obec Hamuliakovo

- monofunkčnost' územia - plošná koncentrácia funkcie bývania v rodinných a bytových domoch, deficit pracovných príležitostí, „parazitovanie“ na pôvodných zariadeniach občianskej a športovej vybavenosti, dopravnej aj technickej infraštruktúre obce; 
- neurčitá sociálno-priestorová identifikácia, ktorá sa prejavuje nedostatkom kvalitných verejných priestorov s funkčnou a významovou diferenciáciou (od parkov a oddychových plôch až po detské ihriska); vysoké, nepriehl'adné oplotenia, ktoré vymedzujú úzky, stiesnený uličný priestor bez zelene, chodníkov a možnosti parkovania (ulica len pre autá), v dôsledku čoho sa obyvatel' uzatvára do súkromia svojho domu (obr. č. 4);

- monotónnost' prostredia spôsobená opakovaním rovnakých typov objektov, výrazových prostriedkov, materiálov a prvkov, čo vedie k strate identity, jedinečnosti a regionálnej rôznorodosti (obr. č. 5);
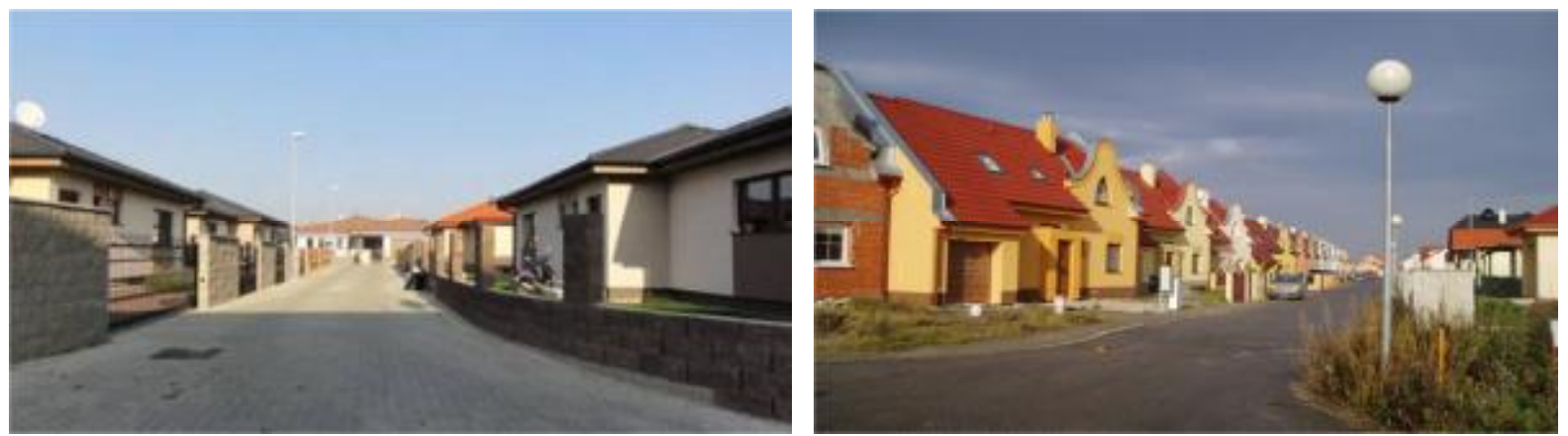

Obr. 4 Monotónna ulica rodinných domov, bez zelene a možnosti parkovania - obec Chorvátsky Grob Obr. 5 Opakovanie rovnakých výrazových prostriedkov - obec Kvetoslavov /foto: Sopirová, 2013/

- nedokončenost' - nová obytná výstavba sa spravidla realizuje dvoma spôsobmi:

- investor postaví celú lokalitu a predáva hotové domy, ak však skrachuje alebo sa dostane do konkurzu, územie zostáva dlhodobo rozostavané, nehnutel'nosti chátrajú, ich hodnota sa postupne znižuje (obr. č. 6),

- investor vybuduje len infraštruktúru a predáva stavebné pozemky, na ktorých individuálny stavebník realizuje dom podl'a vlastného projektu - lokalita sa buduje etapovite, t.j. výstavba je v permanentnom procese (obr. č. 7);
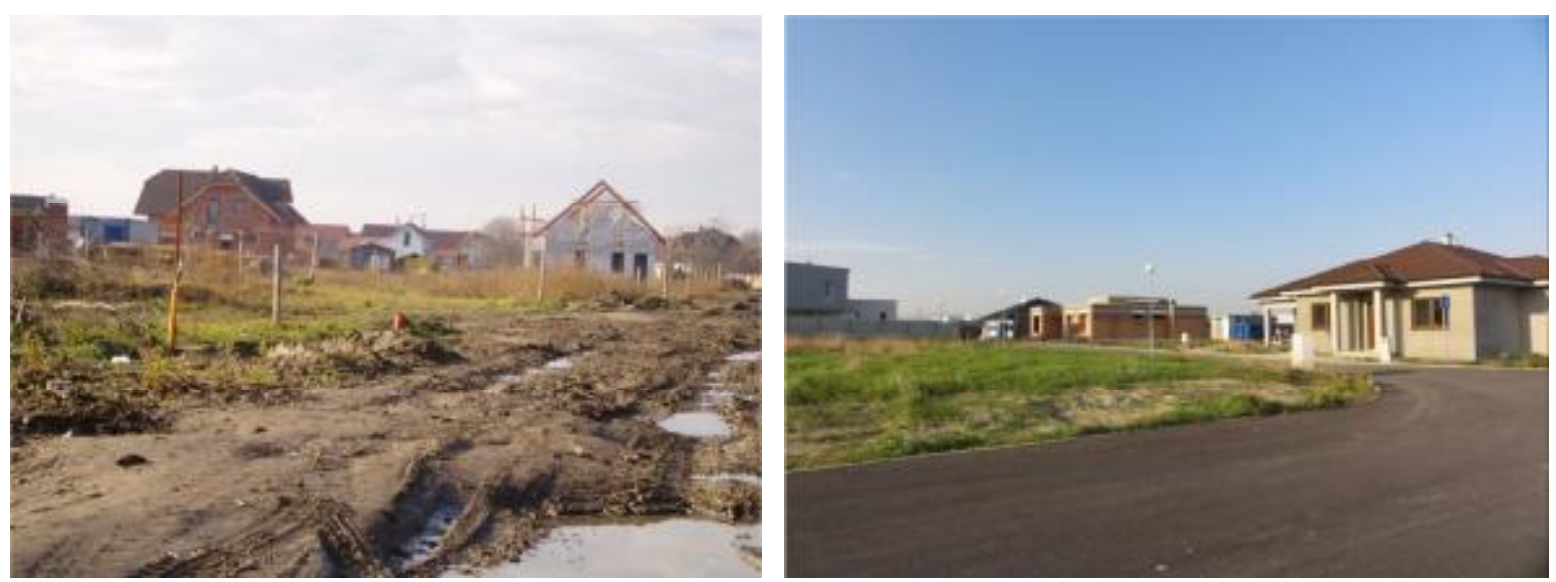

Obr. 6, 7 Dlhodobo rozostavané kolónie rodinných domov - obec Miloslavov /foto: Sopirová, 2013/

- preferencia ekonomických kritérií, ktorá sa vyznačuje zvyšovaním intenzity využitia územia, výstavbou na malých pozemkoch s vyšším koeficientom zastavanosti; úsporou plôch na úkor verejných priestorov, parkov, detských ihrísk, úzkych jednosmerných komunikácií bez chodníkov; uprednostňovaním služieb na komerčnej báze (materské škôlky, zdravotnícke a športové zariadenia); 
- strata miestnej identity $\mathrm{v}$ dôsledku prieniku mestských funkcií a vzorov na vidiek, realizácia „importovanej“ architektúry, ktorá sa vyznačuje výstavbou mestských víl (obr. č. 8), apartmanových foriem bývania, ktoré viažu na seba aj rekreáciu, rozl'ahlých prízemných rodinných domov, ktorých zastavaná plocha presahuje viac ako $50 \%$ výmery pozemku a ich mierka, proporcie a farebnost' sú v kontraste $\mathrm{s}$ pôvodnou vidieckou architektúrou;
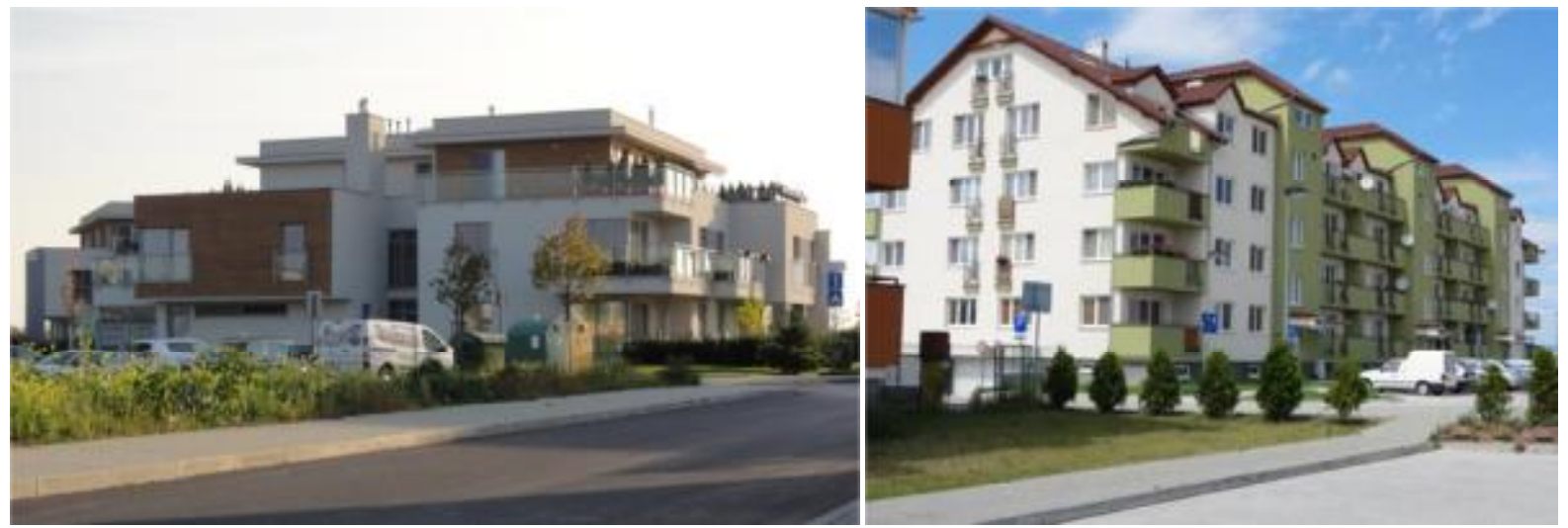

Obr. 8 Výstavba mestských víl ,na zelenej lúke“ pri obci Tureň /foto: Sopirová, 2013/ Obr. 9 Bytové domy tvoria nové vstupné brány do obce Hamuliakovo /foto: Sopirová, 2015/

- komercionalizácia a akcentácia vstupov do sídla - dopĺn̆anie pôvodnej scenérie novými dominantami, ktoré svojou mierkou aj architektonickým dizajnom, prinášajú nenávratné zmeny do vnútorného aj vonkajšieho obrazu a pomeštujú priestor; (obr. č. 9).

\section{EXTRÉMNY STAVEBNÝ ROZVOJ}

Vidiecke sídla, ktoré v územných plánoch obcí majú naplánovaný rozvoj, ktorý niekol'konásobne zväčšuje výmeru pôvodného zastavaného územia obce, počet obyvatel'ov a mení prioritné funkčné využitie obce (obr. 10).

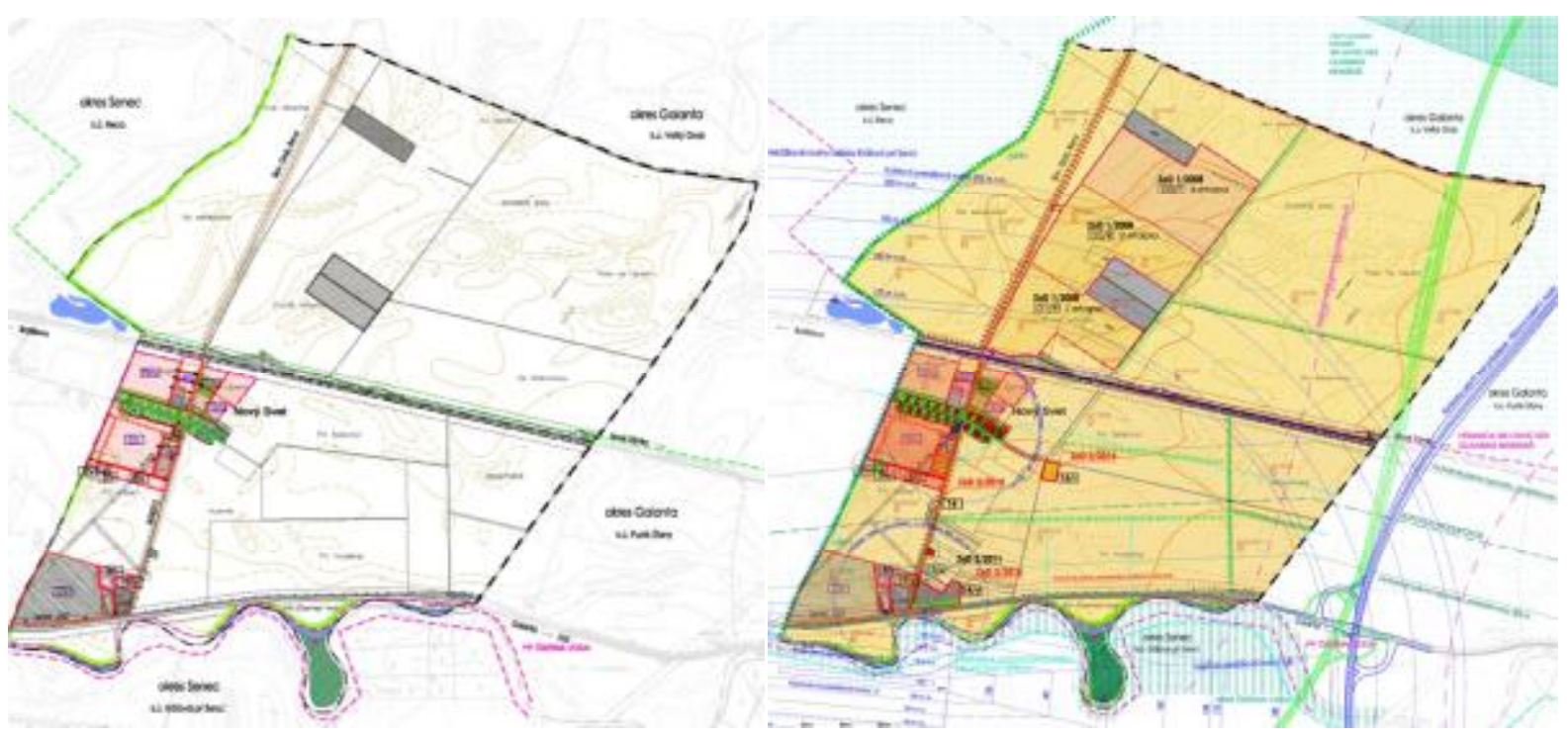

Obr. 10 Obec Nový Svet, nachádza sa vo vzdialenosti 25 km od Bratislavy a 5 km od mesta Senec, ktorá mala v roku 2011 len 71 obyvatel'ov, ale v katastrálnom území naplánované vel'ké investičné zámery územie zamerané na t’ažbu štrku, ktoré po vyt’ažení sa transformuje na rekreačnú funkciu s vodnými plochami (Územný plán obce Nový Svet Zmeny a doplnky, spracovatel’ Sopirová, 2013) 


\section{TRANSFORMÁCIA ŠPECIFICKÝCH ÚZEMÍ NA OBYTNÉ FUNKCIE}

Špecifickým problémom je transformácia pôvodných pol’nohospodárskych a výrobných areálov a objektov, záhradkárskych a chatových osád na obytnú alebo inú funkciu.

Dlhodobo opustené, funkčne nevyužívané pol’nohospodárske objekty, majú spravidla, v dôsledku zanedbanej údržby nevyhovujúci stavebno-technický stav. Negatívny dopad na životné prostredie predstavujú areály a územia poznačené reálnymi alebo potencionálnymi ekologickými zátažami. Tieto predstavujú neprekonatel'né ekonomické bariéry pre sanáciu a možné funkčné využitie. V prípade, ak sa bývalé pol’nohospodárske areály a objekty stanú predmetom kúpy, tak je to spravidla z dôvodu hodnoty pozemku, ktorý sa nachádza $\mathrm{v}$ atraktívnej a výhodnej polohe $\mathrm{z}$ hladiska dopravnej dostupnosti a vybudovanej technickej infraštruktúry. Investor spravidla objekty asanuje, areál sanuje a následne buduje novú obytnú zónu.

Transformáciu špecifickej rekreačnej funkcie pôvodných záhradkárskych a chatových osád na obytné územie, určené pre trvalé bývanie, nepriamo podporuje v súčasnosti platná legislatíva. Pravidlá, ktoré regulovali výstavbu objektov v záhradkárskych osadách (max. $25 \mathrm{~m}^{2}$ - zastavaná plocha záhradnej chatky), v rekreačných a chatových oblastiach (max. $80 \mathrm{~m}^{2}$ - zastavaná plocha rekreačného objektu), boli v roku 2000 zrušené, čím sa otvoril priestor pre neregulovanú výstavbu. „Najväčším problémom funkčnej transformácie týchto území je existujúca dopravná infraštruktúra, tvorená úzkymi účelovými komunikáciami priemernej šírky 3,0 $\mathrm{m}$ až 3,5 m. Ich rekonštrukcii na optimálnu šírku prístupových komunikácií bránia samotní vlastníci, ktorí nechcú presunút vybudované ploty a zariadenia technickej infraštruktúry" (Sopirová, 2013, s. 9).

\section{ZÁVER}

Proces suburbanizácie sa nedá zastavit'. Prijatel'nými stratégiami a územnoplánovacími nástrojmi sa môžu regulovat' jeho negatívne dopady na sídlo a krajinu. Vzhl'adom na to, že intenzita aj efektivita využitia urbanistickej štruktúry väčšiny sídiel ležiacich v zázemí miest na Slovensku je vel'mi nízka „priemerná hustota zastavaného územia vidieckych sídiel sa pohybuje v rozpätí 8,5 až 33,2 ob./ha“ (Sopirová, 2013, s. 48) a tendencie postupného záberu nových plôch pol’nohospodárskej pôdy na stavebné účely narastajú, d’alší rozvoj suburbanizačného priestoru by sa mal sústredit’ na:

- „útlm extenzívneho rozvoja a intenzifikáciu vnútornej štruktúry vidieckych sídiel“ (Sopirová, 2014, s. 55),

- zavedenie prísnejších legislatívnych nástrojov, ktoré obmedzia novú výstavbu na plochách pol'nohospodárskej pôdy.

Pre dosiahnutie plnohodnotného a efektívne fungujúceho obytného prostredia, d’alší rozvoj novej výstavby vo vidieckych sídlach, by sa mal povol'ovat' len pri splnení nasledovných predpokladov:

- vybudovaní potrebnej technickej infraštruktúry v predstihu pred obytnou výstavbou,

- zvýšení miery polyfunkčnosti územia nových obytných zón, efektívnejším využitím územia s optimálnym premiešaním funkcií bývania, občianskej vybavenosti, služieb, rekreácie, športu a práce, čím sa dosiahne dostatočná hustota obyvatel’ov na pokrytie územia hromadnou dopravou,

- dosiahnutí „rovnováhy urbánneho prostredia doplnené prírodným prostredím, rovnováhy aktívneho života doplnené oddychom, rovnováhy komerčného a nekomerčného vybavenia, rovnováhy spoločných, poloverejných a súkromných priestorov" (Bašová, 2014, str. 10). 


\section{Použitá literatúra}

[1] BAŠOVÁ, Silvia: Urbánna vitalita, ALFA 2/2014, FA STU Bratislava, ISSN 1135-2679, str. 10

[2] HNILIČKA, Pavel: Sídelní kaše, Otázky k suburbánní výstavbě rodinných domu, Vydavatelství ERA group, spol. s r.o, 2005, ISBN 80-7366-028-8, str. 27

[3] SMOLEC,Michal: Projekt CENTROP - Rozvoj Bratislavy na zelenej lúke, Bratislava News, máj 2015

[4] SOPIROVÁ, Alžbeta: Súčasnost' a trendy urbanistického rozvoja vidieckych sídiel na Slovensku, Habilitačná príca, FA STU Bratislava, 2013, str. 7, 9,48

[5] SOPIROVÁ, Alžbeta: Sídla v zázemí miest, Slovensko v priestore po dvadsiatich rokoch, ALFA 3/2014, FA STU Bratislava, ISSN 1135-2679, str. 55

[6] ŠTEFANCOVÁ, Lucia: Valorizácia mestotvorných štruktúr, doktorantská práca FA STU Bratislava, 2014, str. 75 